\title{
Antibiotic Susceptibility Profile of Escherichia coli and Salmonella Causing Childhood Diarrhoea in Awka Municipality, South-eastern Nigeria
}

\author{
Ugwu MC ${ }^{1 *}$, Edeani $\mathbf{G I}^{1}$, Ejikeugwu $\mathrm{CP}^{1,2}$, Okezie $\mathrm{U}^{1}$ and Ejiofor $\mathrm{SO}^{3}$ \\ ${ }^{1}$ Department of Pharmaceutical Microbiology and Biotechnology, Faculty of Pharmaceutical Sciences, Nnamdi Azikiwe University, Agulu Campus, Awka, Nigeria \\ ${ }^{2}$ Department of Applied Microbiology, Ebonyi State University, P.M.B 053, Abakaliki, Nigeria \\ ${ }^{3}$ Chukwuemeke Odumegwu Ojukwu University Teaching Hospital (COOUTH) Awka, Nigeria
}

*Corresponding author: Ugwu MC, Department of Pharmaceutical Microbiology and Biotechnology, Faculty of Pharmaceutical Sciences, Nnamdi Azikiwe University, Agulu Campus, Awka, Nigeria, Tel: +2348039460570; E-mail: mc.ugwu@unizik.edu.ng

Received date: April 1, 2017; Accepted date: April 24, 2017; Published date: April 28, 2017

Copyright: ( 2017 Ugwu MC, et al. This is an open-access article distributed under the terms of the Creative Commons Attribution License, which permits unrestricted use, distribution, and reproduction in any medium, provided the original author and source are credited.

\begin{abstract}
Background: In developing countries diarrheal diseases in children are a major public health concern.

Objectives: This study investigated the incidence and antibiotic susceptibility profile of Escherichia coli and Salmonella causing Childhood Diarrhea in Awka.
\end{abstract}

Methods: Twenty six (26) diarrheic stool samples were collected from children $(<5)$ years and cultured. The isolated bacteria were subjected to various identification and biochemical tests. The 44 isolated bacteria (E. coli and Salmonella isolates) were subjected antibiotic susceptibility studies and ESBL-producing screening.

Results: E. coli and Salmonella were detected in 23 (88\%) and 21 (80\%) fecal specimen associated with diarrheal episodes respectively. E. coli showed $91 \%$ resistance to ceftazidime, $100 \%$ resistance to cefuroxime, $78 \%$ resistance to gentamicin, $91 \%$ resistance to ceftriaxone, $78 \%$ resistance to ofloxacin and $100 \%$ resistance to augumentin. Salmonella showed $100 \%$ resistance to ceftazidime, $100 \%$ resistance to cefuroxime, $100 \%$ resistance to gentamicin, $100 \%$ resistance to ceftriaxone, $69 \%$ resistance to ofloxacin and $82 \%$ resistance to augumentin ${ }$. Fifteen $(65.2 \%)$ E. coli isolates were ESBL producers and $8(34.7 \%)$ isolates were non-ESBL producers.

Conclusion: Overall prevalence of $88.5 \%$ of E. coli and $80.8 \%$ of Salmonella spp. were associated with childhood diarrhea in the studied locality. The E. coli and Salmonella spp. were multidrug resistant. Majority (65.2\%) of the E. coli were ESBL producers thus the colonized children may be potential sources of multidrug ESBLproducing $E$. coli strains in the hospital and/or community.

Keywords: Antibiotic resistance; Childhood diarrhea; Enterobacteriacae, Escherichia coli, Salmonella; ESBL

\section{Introduction}

Globally, Diarrheal diseases remain one of the leading causes of morbidity and mortality among children $<5$ years of age [1]. About $21 \%$ of all deaths in children under the age of five (years) are estimated to be due to diarrhoea and related infections. In Sub-Saharan Africa, it is the second leading cause of death in children under 5 years of age [2-4]. About $37 \%$ of all paediatric/childhood deaths in Nigeria are caused by acute diarrhoea, with most of the deaths occurring during the first year of life [5].

Diarrhoea is defined as three or more episodes of watery loose stools in the last 24 hours $[5,6]$. Every episode of diarrhoea in children could cause malnutrition, reduced resistance to infections with potential consequences of impaired physical and cognitive growth/ development [7]. The high prevalence of diarrheal infections in lowincome countries is due to lack of portable drinking water, poor food hygiene standards and inadequate sanitation [7-9].
Diarrhoea causing-microbes are transmitted through contaminated food, water, or direct contact with the improperly sanitized hands of people carrying the pathogens [10,11]. Bacteria, viruses, as well as parasites are all causative organisms for diarrhoea. The most commonly isolated diarrheagenic bacterial pathogens are the Enterobacteriaceae $[4,8]$.

World Health Organization has underlined the importance of epidemiological surveys of childhood diarrhoea in all geographical areas [12]. Information on the etiology of diarrhoea is useful in planning and implementing control strategies to reduce diarrhoeacaused childhood morbidity and mortality in a country. This study is therefore designed to investigate the incidence of entrobactericae as the main etiologic infectious agents of childhood diarrhoea and their antimicrobial susceptibility in the paediatrics units of a hospital in Awka, south-eastern, Nigeria. This we hope will help in infection control measures and equally guide paediatricians in choosing appropriate antibiotics for (empirical) treatment of diarrheal infections. 


\section{Methods}

\section{Ethical considerations}

The study design/objective was explained to the parents/guardian of the children and a verbal consent was obtained from them. The study protocol was approved by the ethical committee of Chukwuemeke Odumegwu Ojukwu University Teaching Hospital (COOUTH) Awka (Ref: COOUTH/AA/VOI.I.008).

\section{Study design}

The inclusion criteria for the study participants were: (a) Being a child less than five years of age; (b) Having diarrhoea that fulfil the WHO criteria for ADD $[13,14]$. Those having a history of antibiotics use two weeks before enrolment were excluded from the study. A questionnaire was used to collect participants' information: age, sex, area of residence, socio-economic stratum, days of diarrhoea, date of collection etc. The mother or guardian of any child that met the inclusion criteria for sample collection was given a stool container and instructions for sample collection.

\section{Bacterial isolation and identification}

Stool samples collected in universal container, were inoculated using an inoculating loop of $10 \mu \mathrm{L}$ volume calibration, into sterile nutrient broth contained in test tubes. All inoculated nutrient broths were incubated aerobically overnight at $37^{\circ} \mathrm{C}$. After incubation, the broth cultures were examined for significant growth. A loop full from the culture in each broth, were streaked directly on well labelled MacConkey and Salmonella-Shigella agar, incubated at $37^{\circ} \mathrm{C}$ for $24 \mathrm{~h}$. After incubation, cultures were examined for significant growth. Subcultures were prepared into plates of nutrient agar, and incubated for another $24 \mathrm{~h}$. The isolates were stored at $4^{\circ} \mathrm{C}$ for further biochemical/identification studies: Gram staining, colony morphology and biochemical test (Indole, mannitol, TSI test, etc). The organisms were identified as E. coli and Salmonella spp. on the basis of colony morphology, Gram staining, motility, and biochemical reactions.

\section{Antibiotic susceptibility test}

Antibiotic susceptibility profiles of the bacterial isolates were evaluated using disk diffusion assay as described by Ekwealor et al. [15]. The antibiotic disc (ABTEK, India) containing the following antibiotics (disc content) was used: Ceftazidime $(30 \mu \mathrm{g})$, Cefuroxime $(30 \mu \mathrm{g})$, Gentamicin $(10 \mu \mathrm{g})$, Ceftriaxone $(30 \mu \mathrm{g})$, Erythromycin $(5 \mu \mathrm{g})$, Cloxacillin $(5 \mu \mathrm{g})$, Ofloxacin $(5 \mu \mathrm{g})$ and Augmentin $(30 \mu \mathrm{g})$. Standardized overnight culture of each isolate was seeded in melted Mueller-Hinton agar (MHA) at $45^{\circ} \mathrm{C}$ and aseptically poured into sterilized plates (in triplicate). The plates were allowed to solidify and the antibiotic disks were aseptically placed on the surface of the culture media. The MHA plates were thereafter incubated at $37^{\circ} \mathrm{C}$ for $18-24 \mathrm{~h}$. After incubation, the inhibition zones were measured and interpreted by the recommendations of the Clinical and Laboratory Standards Institute $[16,17]$.

\section{ESBL detection test}

The E. coli were first screened by phenotypic method for ESBL production and then phenotypically confirmed as per CLSI guidelines as described by Ejikeugwu et al. [16]. ESBL production was confirmed phenotypically in the $E$. coli isolates that showed reduced susceptibility to any of the screening antibiotic disks of ceftazidime, cefotaxime, and ceftriaxone used. These agents were used for screening to improve the sensitivity of ESBL detection as recommended by CLSI [17]. ESBL production was confirmed if there is an increase of $\geq 5 \mathrm{~mm}$ in inhibition zone diameter for either of the cephalosporins (ceftazidime and cefotaxime) tested in combination with amoxycillin-clavulanic acid compared to its zone when each antibiotic is tested alone.

\section{Results}

\section{Characteristics of the study cohort}

Majority of the Diarrhoea cases were reported from the out-patient department, very few were admitted into the in-patient department. Many of the houses where the patients came from had modern features: Table 1 shows the characteristics of the study participants. Among the study participants $100 \%$ had electricity and refrigerator, $50 \%$ had washing machine, and $50 \%$ had cooking gas. Though no municipal water system, $70 \%$ of water is gotten from private provider and $30 \%$ from roof, jerry can for $50 \%$ of the patients, the other $50 \%$ get water from private providers only. The presence of sanitary water closet is reported in $50 \%$ and $50 \%$ sanitary latrine. Refuse containers were found in $100 \%$ of houses either inside or outside the dwelling. Fifty per cent (50\%) boil water before drinking, 50\% drink tap water while $50 \%$ had domestic animals like dog and chicken in the house.

\begin{tabular}{|l|l|}
\hline Characteristics & Percentage \\
\hline Electricity and refrigerator & $100 \%$ \\
\hline Washing machine & $50 \%$ \\
\hline Cooking gas & $50 \%$ \\
\hline Water from private provider & $70 \%$ \\
\hline Water from roof jerry can & $30 \%$ \\
\hline Sanitary water closet & $50 \%$ \\
\hline Sanitary latrine & $50 \%$ \\
\hline Refuse container in the house & $100 \%$ \\
\hline Boil water for drinking & $50 \%$ \\
\hline Tap water for drinking & $50 \%$ \\
\hline Domestic animals & $50 \%$ \\
\hline
\end{tabular}

Table 1: Percentage characteristics of the study cohort.

\begin{tabular}{|l|l|l|}
\hline Isolates & Number & Percentage \\
\hline Escherichia coli & 23 & $88.5 \%$ \\
\hline Salmonella spp. & 21 & $80.8 \%$ \\
\hline Total & 44 & \\
\hline
\end{tabular}

Table 2: Percentage incidence of the bacterial isolates.

\section{Incidence of diarrhoea}

A total of 26 diarrhoea stool samples were collected from the paediatric hospital in Awka Metropolis. Of the 26 diarrhoea stool 
samples collected, E. coli was detected in 23 (88\%) faecal specimen associated with diarrheal episodes. Salmonella spp. were also detected in 21 (80\%) faecal specimen of diarrheal episodes (Table 2).

\section{Antibiotic susceptibility and MARI}

Figure 1 shows the resistance pattern of the isolated bacteria. Erythromycin and cloxacillin did not inhibit the growth of either of the organisms. E. coli showed $91 \%$ resistance to ceftazidime, $100 \%$ resistance to cefuroxime, $78 \%$ resistance to gentamicin, $91 \%$ resistance to ceftriaxone, $78 \%$ resistance to ofloxacin and $100 \%$ resistance to augumentin (Table 3). Salmonella spp. showed $100 \%$ resistance to ceftazidime, $100 \%$ resistance to cefuroxime, $100 \%$ resistance to gentamicin, $100 \%$ resistance to ceftriaxone, $69 \%$ resistance to ofloxacin and $82 \%$ resistance to augumentin. The two bacterial species recorded a high MAR indices of 50\% (E. coli) and 75\% (Salmonella).

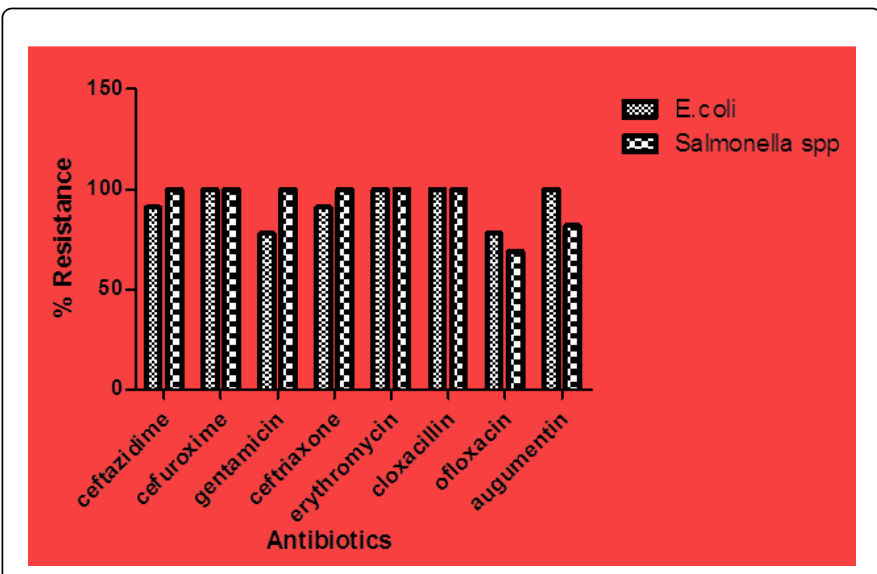

Figure 1: Percentage resistance of the bacterial isolates.

\begin{tabular}{|l|l|l|l|l|}
\hline Organism & $\begin{array}{l}\text { No. of antibiotics } \\
\text { resisted by Isolates }\end{array}$ & $\begin{array}{l}\text { No. of antibiotics } \\
\text { tested }\end{array}$ & MARI & $\begin{array}{l}\text { Percentag } \\
\text { e }\end{array}$ \\
\hline E. coli & 4 & 8 & 0.5 & $50 \%$ \\
\hline Salmonella & 6 & 8 & 0.75 & $75 \%$ \\
\hline
\end{tabular}

Table 3: Multiple antibiotic resistance index of bacterial isolates.

\section{ESBL detection}

Of the total $E$. coli isolates, 15 (65.2\%) isolates were ESBL producers and $8(34.7 \%)$ isolates were non-ESBL producers (Table 4). Figure 2 shows a pictorial effect produced by $E$. coli isolate expressing ESBL. This is characteristic of ESBL-producing bacteria because of the synergistic effect produced between a beta-lactamase inhibitor, amoxicillin-clavulanic acid, and any of the third generation cephalosporins (ceftazidime and cefotaxime).

\begin{tabular}{|l|l|l|}
\hline Isolates & Number & Percentage \\
\hline ESBL Producers & 15 & $65.20 \%$ \\
\hline Non ESBL Producers & 8 & $34.70 \%$ \\
\hline
\end{tabular}

Table 4: ESBL detection.

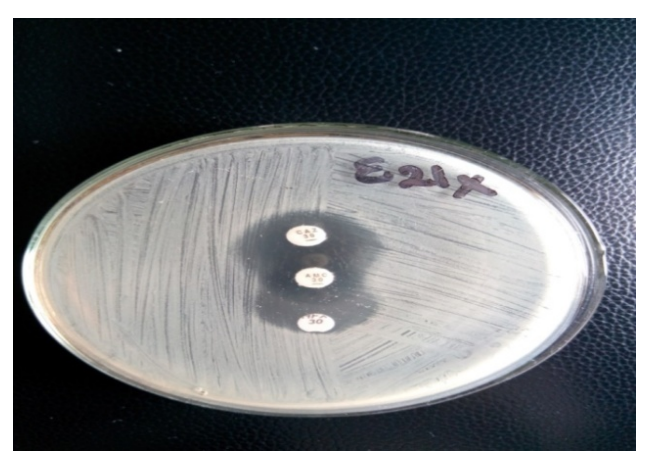

Figure 2: Mueller-Hinton agar plate showing phenotypic detection of ESBL production using the double disk synergy test (DDST) method. The bacterium is $P$. aeruginosa; the antibiotic disk on the left is ceftazidime $(30 \mu \mathrm{g})$ while the disk on the right is cefotaxime $(30 \mu \mathrm{g})$. The central disk is amoxycillin-clavulanic acid, a betalactamase inhibitor.

\section{Discussion}

Diarrheal diseases are the second leading cause of death in children less than 5 years of age. Information about household characteristics in a locality and their interrelation with diarrhoea prevalence among the children aged five years is very crucial in the infection control measures, for effective reduction of childhood morbidity and are required to make important policy decisions [6,12]. Similarly, antibiotic susceptibility testing plays a useful role in the outbreak setting and for surveillance of local trends in resistance patterns and mechanisms [6]. In this study, we highlight the importance of environmental influence on the risk of diarrhoea associated with Enterobactericea during childhood. Children living in poor households are more vulnerable to diarrhoea than their wealthy counterparts [18]. The presence of a refuse container in the homes will likely increase overall risk of diarrhoea associated with $E$. coli. This association of refuse containers in the home was expected as refuse containers mostly uncovered in the study households, providing children with easy access to debris and could attract flies carrying the pathogens. Improper faecal disposal as well as lack of clean water leads to contamination of groundwater especially in areas where water filtration or purification processes are not practiced. This can help in the widespread of some bacterial pathogens among children $[18,19]$. Also the use of water sourced from Jerri can roof in cleaning household utensils and the presence of domestic animals in the house is also risk factors of $E$. coli associated in childhood diarrhoea. The associations strongly suggest that behavioral-hygienic and cleanliness in the household affect disease incidence. Contaminated food or drinking-water, or from person-to-person as a result of poor hygiene are known to be common means of spreading Diarrheal infection [19]. Studies have reported that variables like age of the child, quality and quantity of water, availability of toilet facilities, housing conditions, level of maternal education, household economic status etc., affect the exposure to diarrhoea pathogens and infections [18] We reported that an $88 \%$ and $80 \%$ faecal specimen yielded E. coli and Salmonella spp. respectively of diarrheal episodes This implies that there is co-infection among the study participants. Co-infection by multiple groups of enteric pathogens has been demonstrated to be the norm in diarrhoea cases [20]. The possible reasons are: (i) that when one intestinal 
pathogen infects the body, the infection rate of other pathogens increases [21]; (ii), these are foodborne pathogens and can be found in the same contaminated foods increasing the likelihood of mixed infections in risk populations. It has been reported that co-infections with multiple enteric pathogens occur mainly in zones with poor quality of food, drinking water and poor sanitary conditions in the environment [20,22]. Co-infection among children with diarrhoea may cause more severe diarrhoea than infection with a single pathogen and can also increase treatment costs $[20,23]$.Thus we suggest that it is important to consider enteric pathogens rather than just single pathogen in every epidemiological study evaluating diarrhoea-causing agents in poor countries.

A similar percentage yield of $64 \%$ bacterial isolates of the stool samples has been reported in Kaduna, Northwestern Nigeria [24]. However, our prevalence differed from $25.1 \%$ reported in 2009 by Nweze [25].

A low susceptibility of the diarrheic organisms was observed with third generation cephalosporin (ceftazidime, cefuroxime, and ceftriaxone). The E. coli isolates showed moderate susceptibiltity to ofloxacin and gentamicin, while Salmonella responded better to ofloxacin and augmentin". In line with our results, similar sensitive response to the flouroqunolones was equally reported by Eseigbe et al. [24]. Contrary to our results, in Niger Langendorf et al., [26] reported that most of the diarrheic E. coli and Salmonella were sensitive to antibiotics tested except amoxicillin and co-trimoxazole. Guerra et al. [27] also reported no resistance to ceftriaxone, ceftazidime and cefepime by Enterotoxigenic Escherichia coli clinical isolates from Northern Colombia. The MAR Index for each isolate was calculated using the relationship between the number of antibiotics to which the isolate was resistant divided by the number of antibiotics tested. Value lower than 0.2 , is considered low risk, while higher than 0.2 is indicates high risk $[28,29]$. The high MARI value observed in the study may be due to the widespread use of antibiotics in the locality $[28,30]$. In the present study, out of 23 E. coli, $65.2 \%$ (15/23) were ESBL producers by phenotypic confirmatory methods. In line with our finding, a similar high ESBL-producing was recorded of Escherichia coli isolated from Children with Acute Diarrhoea in Wrocław, Poland [31]. The high prevalence of ESBL-producing among the $E$. coli isolates is a big concern as they might show a false sensitive zone of inhibition in the Kirby-Bauer disk diffusion method and often remain undetected by routine susceptibility tests $[26,32]$. The prevalence of ESBL producing $E$. coli varies from country to country and from center to center. In the United States, ESBL producing E. coli ranges from $0-25 \%$ with the average being around 3\% [33]. ESBL producers may have spared through communities, especially those with poor hygienic and sanitation conditions, through faecal contamination of soil and water, since most patients with ESBL producers may have had their gastrointestinal tracts colonized by these organisms [34]. $\beta$-lactamase production is perhaps the most reported important mechanism of resistance to penicillin and cephalosporins and E. coli is known to possess a naturally occurring chromosomally mediated and/or plasmid-mediated $\beta$-lactamases [17,31].

\section{Conclusion}

Our findings show that a high percentage of childhood diarrhoea are caused by antibiotic-resistant bacteria as most $E$. coli and Salmonella isolates in our study demonstrated multidrug resistance to conventional antibiotics. Majority $(65.2 \%)$ of the E. coli were ESBL producers thus the colonized children may be potential sources of multidrug ESBL-producing E. coli strains in the hospital and or/ community. However, because of the safety issues with the use of fluoroquinolones in paediatrics we recommend the use of Augmentin in the management of childhood diarrhoea in the studied locality with adequate fluid replacement and zinc supplement, while high hygiene practices should be encouraged.

\section{References}

1. Yeshwondm M, Gesit M, Asaye B, Kassu D, Surafel F (2015) Isolation and Antibiotic Susceptibility Patterns of Shigella and Salmonella among Under 5 Children with Acute Diarrhoea: A Cross-Sectional Study at Selected Public Health Facilities in Addis Ababa, Ethiopia. Clin Microbiol 4: 1-7.

2. O'Ryan M, Prado V, Pickering LK (2005) A millennium update on pediatric diarrheal illness in the developing world. Semin Pediatr Infect Dis 16: 125-136.

3. Kosek M, Bern C, Guerrant RL (2003) The global burden of diarrhoeal disease, as estimated from studies published between 1992 and 2000. Bull World Health Organ 81: 197-204.

4. Altinier V, Martin G (2017) Diarrhea Caused by Shiga-Toxigenic Escherichia Coli, other Pathogens and HUS. Effects of Bismuth Hydroxide Gel. Gastroenterol Hepatol Open Access 6: 1-4.

5. Mandomando IM, Macete EV, Ruiz J, Sanz S, Abacassamo F, et al. (2007) Etiology of diarrhea in children younger than 5 years of age Admitted in a rural hospital of southern mozambique. Am J Trop Med Hyg 76: 522-527.

6. Riddle MS, DuPont HL, Connor BA (2016) ACG Clinical Guideline: Diagnosis, Treatment, and Prevention of Acute Diarrheal Infections in Adults. Am J Gastroenterol 126: 1-21.

7. UNICEF (2015) Water, sanitation and hygiene: The case for support 1-14.

8. Hamer DH, Simon F, Thea D, Keush GT (1998) Childhood diarrhea in Sub-Saharan Africa. Child Health Research Project Special Report 2: 1-32.

9. Akinyemi KO, Iwalokun BA, Foli F, Oshodi K, Coker AO (2011) Prevalence of multiple drug resistance and screening of enterotoxin gene (stn) in Salmonella enterica serovars from water sources in Lagos, Nigeria. Public Health 125: 65-71.

10. Songe MM, Hangombe BM, Knight-Jones TJD, Grace D (2017) Antimicrobial Resistant Enteropathogenic Escherichiacoli and Salmonella spp. in Houseflies Infesting Fishing Food Markets in Zambia. Int J Environ Res Public Health 14: 1-10.

11. Podewils LJ, Mintz ED, Nataro JP, Parashar UD (2004) Acute, infectious diarrhea among children in developing countries. Semin Pediatr Infect Dis 15: 155-168.

12. Tambe AB, Nzefa LD, Nicoline NA (2015) Childhood Diarrhea Determinants in Sub-Saharan Africa: A Cross Sectional Study of TikoCameroon. Challenges 6: 229-243.

13. World Health Organization (2005) The treatment of diarrhoea: a manual for physicians and other senior health workers. 4th revision. Geneva: Dept. of Child and Adolescent Health and Development World Health Organization.

14. Gómez-Duarte OG, Yesenia CR, Paez-Canro CZ, Eslava-Schmalbach JH, Arzuza O (2013) Enterotoxigenic Escherichia coli associated with childhood diarrhoea in Colombia, South America. J Infect Dev Ctries 7: 372-381.

15. Ekwealor PA, Ugwu MC, Ezeobi I, et al. (2016) Antimicrobial Evaluation of Bacterial Isolates from Urine Specimen of Patients with Complaints of Urinary Tract Infections in Awka, Nigeria. Int J Microbiol 2016: 1-7.

16. Chika E, Ugwu M, Ifeanyichukwu I, Thaddeus G, Carissa D, et al. (2013) Detection and antimicrobial susceptibility of some gram negative bacteria producing carbapenemases and extended spectrum $\beta$-Lactamases. Int J Microbiol Immunol Res 2: 064-069.

17. Clinical and Laboratory Standards Institute (2016) Performance Standards for Antimicrobial Susceptibility Testing M100S, 26th ed. 
Citation: Ugwu MC, Edeani GI, Ejikeugwu CP, Okezie U, Ejiofor SO (2017) Antibiotic Susceptibility Profile of Escherichia coli and Salmonella Causing Childhood Diarrhoea in Awka Municipality, South-eastern Nigeria. Clin Microbiol 6: 277. doi:10.4172/2327-5073.1000277

Page 5 of 5

18. Kwasi OB, Markku K (2005) Childhood diarrheal morbidity in the Accra Metropolitan Area, Ghana: socio-economic, environmental and behavioral risk determinants. J Health Population Dev Ctries 1-11.

19. Mero WMS, Jamee AY, Amidy KSK (2015) Microorganisms and viruses causing diarrhea in infants and primary school children and their relation with age and sex in Zakho city, Kurdistan Region, Iraq. Int J Res Med Sci 3: 3266-3273.

20. Zhang S, Yong-Ming Z, Wen X, Li-Guang T, Jia-Xu C, et al. (2016) Impact of co-infections with enteric pathogens on children suffering from acute Diarrhea in southwest China. Infect Dis Poverty 5: 1-13.

21. Mukherjee AK, Chowdhury P, Rajendran K, Nozaki T, Ganguly S (2014) Association between Giardia duodenalis and coinfection with other diarrhea-causing pathogens in India. Biomed Res Int 2014: 786480.

22. Vu NT, Le Van P, Le Huy C, Nguyen GK, Weintraub A (2006) Etiology and epidemiology of diarrhea in children in Hanoi, Vietnam. Int J Infect Dis 10: 298-308.

23. Li LL, Liu N, Humphries EM, Yu JM, Li S, et al. (2016) Aetiology of diarrhoeal disease and evaluation of viral-bacterial coinfection in children under 5 years old in China: a matched case-control study. Clin Microbiol Infect 22: 1-8.

24. Eseigbe EE, Iriah S, Ibok S, Anyanwu F, Eseigbe P, et al. (2013) Bacterial isolates from the stools of children aged less than 5 years with acute diarrhea in Kaduna, Northwestern Nigeria. Ann Trop Med Public Health 6: 452-455.

25. Nweze EI (2009) Virulence properties of diarrheagenic E.Coli and etiology of Diarrhoea in infants, young children and other age groups in Southeast Nigeria. Am-Euras J Sci Res 4: 173-179.

26. Langendorf C, Le Hello S, Moumouni A, Gouali M, Mamaty AA, et al. (2015) Enteric Bacterial Pathogens in Children with Diarrhea in Niger: Diversity and Antimicrobial Resistance. PLoS One 10: 1-18.
27. Guerra JA, Romero-Herazo YC, Arzuza O, Gómez-Duarte OG (2014) Phenotypic and Genotypic Characterization of Enterotoxigenic Escherichia coli Clinical Isolates from Northern Colombia, South America. BioMed Res Int 10: 1-11.

28. Ugwu MC, Ikegbunam MN, Nduka SO, Attama AA, Ibezim EC, et al. (2013) Molecular Characterization and Efficacy of Antibiotic Combinations on Multiple Antibiotic-Resistant Staphylococcus aureus Isolated from Nostrils of Healthy Human Volunteers. J Pharm Sci \& Res 5: 26-32.

29. Oluyege JO, Dada O, Oluyege AO, Olowomoofe TO (2014) Multiple antibiotic resistance index of Escherichia coli isolated from drinking water source in Ado-Ekiti, Nigeria.The Experiment 28: 1896-1905.

30. Ugwu MC, Mokwe N, Ejikeugwu PC, Enemor EC, Eze CO, et al. (2015) Antibiogram of Staphylococcus Aureus from Healthy School Pupils in Agulu, Southeastern Nigeria. International Journal of Research in Pharmacy and Biosciences 2: 5-9.

31. Franiczek R, Sobieszczańska B, Turniak M, Kasprzykowska U, Krzyzanowska B, et al. (2012) ESBL-Producing Escherichia coli Isolated from Children with Acute Diarrhea-Antimicrobial Susceptibility, Adherence Patterns and Phylogenetic Background. Adv Clin Exp Med 21: 187-192.

32. Subha A, Ananthan S (2002) Extended spectrum $\beta$-lactamase (ESBL) mediated resistance to third generation cephalosporins among Klebsiella pneumoniae in Chennai. Indian J Med Microbiol 20: 92-95.

33. National Nosocomial Infections Surveillance System (2004) National Nosocomial Infections Surveillance (NNIS) System Report, data summary from January 1992 through June 2004, issued October 2004. Am J Infect Control 32: 470-485.

34. Paterson DL, Bonomo RA (2005) Extended-spectrum $\beta$-lactamases: a clinical update. Clin Microbiol Rev 18: 657-686. 